\title{
Patient-centred and not disease-focused: a review of guidelines and multimorbidity
}

\author{
Kim Yao Ong ${ }^{1}$, Poay Sian Sabrina $\underline{L e}^{2}$, PhD, Eng Sing $\underline{L e e^{2}}$, MBChB, FCFP
}

INTRODUCTION Single-disease clinical practice guidelines (CPGs) are not designed to consider patients with multiple chronic conditions, or multimorbidity. Applying multiple CPGs to a single patient may create an overwhelming treatment burden resulting in poor adherence and clinical outcomes. No studies on the cumulative treatment burden from multiple CPGs have been done in Singapore. We described the treatment burden on a hypothetical patient with six chronic conditions when multiple CPGs were applied, and appraised each CPG with respect to the patient-centred care of older adults with multimorbidity.

METHODS A treatment plan was developed for a hypothetical 72-year-old woman with asthma, depression, diabetes mellitus, dyslipidaemia, hypertension and osteoarthritis according to the latest CPG recommendations. Treatment burden was quantified in terms of time spent, cost, and the number of appointments and medications. Each CPG was appraised with respect to the care of older adults, patients with multimorbidity and patient-centred care.

RESULTS Following the CPGs strictly, an average of about two hours was spent daily taking 14 different medications and following 21 non-pharmacological recommendations. Her out-of-pocket payment was SGD 104.42 monthly despite a near $90 \%$ subsidy on healthcare bills. Patient-centred care of older adults with multimorbidity was inadequately addressed in all six CPGs.

CONCLUSION When six CPGs were cumulatively followed, the treatment burden was time-consuming, costly and disruptive. Patients' goals and preferences must guide prioritisation of care such that treatment burden remains minimally disruptive to their lives. Developing future CPGs to deliver patient-centred rather than disease-focused care will be crucial to the management of multimorbidity.

Keywords: chronic disease, comorbidity, multimorbidity, practice guidelines, primary care

\section{INTRODUCTION}

Multimorbidity is the co-occurrence of two or more chronic conditions in an individual. ${ }^{(1,2)}$ It is associated with increasing age and is most prevalent among older adults. ${ }^{(3)}$ Managing multimorbidity is challenging, as current healthcare systems are predominantly guided by single-disease pathways. ${ }^{(4)}$ For example, most clinical practice guidelines (CPGs) have a single-disease focus. ${ }^{(5)}$ They inadequately address patients with multimorbidity ${ }^{(5)}$ in whom treatment burden, defined as the total healthcare workload experienced by these patients, ${ }^{(6)}$ is cumulative. Consequently, these patients experience a poor quality of life, high healthcare expenditures, polypharmacy, and increased risk for adverse drug events and mortality ${ }^{(7)}$ in a healthcare system with poor coordination and integration. ${ }^{(8)}$ In Singapore, where one in five Singaporeans will be aged 65 years or older by $2030,{ }^{(9)}$ it is imperative to optimise management of multimorbidity. Following multiple single-disease CPGs may create an overwhelming treatment burden that leads to poor adherence, wasted resources and poor clinical outcomes. ${ }^{(10)}$ While previous studies examining international guidelines have found that treatment burden greatly increases with an increasing number of chronic conditions, ${ }^{(11-13)}$ no similar studies have been conducted in Singapore.

We aimed to identify gaps in current CPGs that run contrary to the goal of patient-centred care, which is for treatment burden to be minimally disruptive to patients' lives. The primary study objective was to describe the treatment burden of a hypothetical patient with six common chronic conditions in the primary care setting when multiple single-disease CPGs are applied. The secondary objective was to appraise the extent to which CPGs address older adults, multimorbidity and patient-centred care.

\section{METHODS}

A treatment plan was developed for our hypothetical patient $\mathrm{Mdm}$ Wong, a 72-year-old widow with asthma, depression, diabetes mellitus, dyslipidaemia, hypertension and osteoarthritis, all moderate in severity, based on the latest CPG recommendations (Appendix 1). Mdm Wong lives alone and receives a monthly annuity of SGD 650 from her Central Provident Fund account, the mandatory national savings scheme in Singapore, ${ }^{(14)}$ and visits the nearest polyclinic for her multimorbidity. For the purpose of this study, generic medications with the least frequent dosing regimen and combined recommendations applicable to multiple CPGs were chosen whenever possible.

From the 20 chronic conditions that are under the Ministry of Health $(\mathrm{MOH})$ Chronic Disease Management Programme and therefore eligible for subsidies (Appendix 2), (15) six conditions commonly managed in the primary care setting were selected, including a chronic pain condition (osteoarthritis) and a mental health condition (depression), to reflect the full breadth of multimorbidity. MOH CPGs produced within the last ten years

${ }^{1}$ Lee Kong Chian School of Medicine, Nanyang Technological University, ${ }^{2}$ Clinical Research Unit, National Healthcare Group Polyclinics, Singapore Correspondence: Dr Lee Eng Sing, Principal Clinician Researcher, Clinical Research Unit, National Healthcare Group Polyclinics, 3 Fusionopolis Link, Nexus@one-north, South Lobby, \#05-10, Singapore 138543. eng_sing_lee@nhgp.com.sg 
were selected, as they are most appropriately matched to local practice. As the $\mathrm{MOH}$ CPGs for asthma and osteoarthritis had not been updated in the past ten years, international guidelines that are most often used locally (Appendix 2) were selected, ${ }^{(16-21)}$ namely the Global Strategy for Asthma Management and Prevention guidelines from the Global Initiative for Asthma and the Osteoarthritis: Care and Management in Adults guidelines from the National Institute for Health and Care Excellence (NICE). CPGs were evaluated based on criteria selected from similar studies examining the applicability of guideline recommendations to older adults, patients with multimorbidity and patient-centred care. ${ }^{(11,13)}$

Treatment burden concerning time spent, cost, and the number of appointments and medications was quantified. Estimates of time spent on various health-related activities (HRAs) were obtained from the published literature ${ }^{(22,23)}$ and operational data from the National Healthcare Group Polyclinics (NHGP) (Appendix 3). Both subsidised and unsubsidised costs of treatment in the primary care setting were calculated. The unsubsidised costs included the national goods and services tax (GST) at the prevailing rate of $7 \%$ to reflect the true cost to the healthcare system. The out-of-pocket payment by Mdm Wong after $\mathrm{MOH}$ subsidy with GST absorbed, and additional coverage from the Pioneer Generation Package (PGP), which entitles patients to an additional $50 \%$ off their subsidised healthcare bill, (24) and the Community Health Assist Scheme (CHAS), which enables patients to make claims up to SGD 135 per visit and SGD 54 per year from their Medisave account, ${ }^{(25)}$ were also reported. This was expressed as a percentage of her monthly annuity. Treatment for acute exacerbations of chronic diseases was not considered.

\section{RESULTS}

For this study, treatment burden was shown in terms of a total of 21 non-pharmacological recommendations (Box 1 \& Table I). These included six referrals, eight laboratory tests and five patienteducation interventions, equating to 53 polyclinic appointments annually for Mdm Wong. She would take 14 different types of medications, equivalent to 32.5 pills taken at five different times daily, assuming that 'as needed' salbutamol is taken once daily before exercise, paracetamol thrice daily and kefentech plasters twice daily for pain relief (Table II). In addition, she would spend up to $64.53 \mathrm{hr} / \mathrm{mth}(2.15 \mathrm{hr} /$ day) on HRAs, including $7.87 \mathrm{hr} / \mathrm{mth}$ attending appointments, $8.67 \mathrm{hr} / \mathrm{mth}$ monitoring her diseases, $12.00 \mathrm{hr} / \mathrm{mth}$ taking medications, $16.00 \mathrm{hr} / \mathrm{mth}$ following the recommended diet and $20.00 \mathrm{hr} / \mathrm{mth}$ on exercise.

Table III shows the expected treatment costs for $\mathrm{Mdm}$ Wong. Without subsidies, a total of SGD 447.72 (SGD 236.64 for medications), $68.9 \%$ of her monthly annuity, would be spent monthly. After $\mathrm{MOH}$ and PGP subsidies, the monthly payment would decrease to SGD 104.42 monthly (SGD 49.97 for medications), $16.1 \%$ of her monthly annuity. This equates to a more than $50 \%$ reduction in her monthly payment. Unfortunately, her annual CHAS claim limit (of SGD 540 per year) would be exhausted in five months and she would have
Box 1. Recommended non-pharmacological patient tasks based on clinical practice guidelines (CPGs). CPGs used for each recommendation are indicated in brackets:

1. Diet $(D M, L, H T)$

(a) Medical nutritional therapy for DM

(b) DASH diet (i.e. Dietary Approaches to Stop Hypertension) for HT

(c) Low trans-fat, saturated fat, cholesterol, refined grains, simple sugars, salt

(d) High dietary fibres (whole grain, fruits, vegetables)

2. Weight loss of $5 \%-10 \%$ of total body weight, $\mathrm{BMI}<23 \mathrm{~kg} / \mathrm{m}^{2}$ and waist circumference $<90 \mathrm{~cm}$ (male) or $<80 \mathrm{~cm}$ (female)

(A, DM, L, HT, OA)

3. Exercise (A, DP, DM, L, HT, OA)

(a) $\geq 150 \mathrm{~min} / \mathrm{wk}$

(b) $\geq 30 \mathrm{~min} /$ day

(c) Moderate intensity aerobic and dynamic exercises for cardiovascular health

(d) Local muscle strengthening, manipulation and stretching (range-of-motion exercises) for knee OA

(e) Breathing exercises for asthma

4. Appropriate footwear (DM, OA)

5. Avoid environmental exposures that may exacerbate asthma,

e.g. tobacco smoke, pollutants and allergens (A)

6. Written asthma action plan (A)

7. Activity pacing $(\mathrm{OA})$

8. Home monitoring (A, DM, HT)

(a) Foot checks daily

(b) Self-monitoring of capillary blood glucose thrice weekly

(c) Self-monitoring of home blood pressure once weekly

(d) Self-monitoring of asthma symptoms and/or peak expiratory flow daily

A: asthma; DP: depression; DM: diabetes mellitus; HT: hypertension; L: dyslipidaemia; OA: osteoarthritis

to make monthly out-of-pocket payments of SGD 104.42 for the remaining months (Table III). The treatment regimen would cost the healthcare system SGD 5,372.68 annually (SGD 2,839.67 for medications).

Although each individual CPG considers older adults, only four of the CPGs (asthma, depression, dyslipidaemia and hypertension) have dedicated sections with extensive information and evidence (Table IV). Across the six CPGs, recommendations range from modified treatment targets (dyslipidaemia and diabetes mellitus) to specific pharmacological recommendations (hypertension and depression). Most pertain to the increased risk of adverse effects and drug interactions in older adults. Among the recommendations for older adults, only five are based on the highest level of evidence. All except the osteoarthritis CPG mention at least one specific comorbidity (Table IV), and this is most extensive in the hypertension CPG. However, none of the CPGs address multimorbidity or multiple comorbidities. All CPGs include patients' goals and preferences. Three CPGs (dyslipidaemia, hypertension and osteoarthritis) recommend tailoring treatment to the patient, but with no disease-specific elaboration. The other three CPGs (asthma, diabetes mellitus and depression) discuss patient preferences regarding specific treatment options or targets. None of the CPGs address the time needed to treat to benefit (Table IV). 
Table I. Recommended non-pharmacological clinician tasks based on clinical practice guidelines.

\begin{tabular}{|c|c|c|c|c|}
\hline \multirow[t]{2}{*}{ Recommendation } & \multirow[t]{2}{*}{ Frequency } & \multirow{2}{*}{$\begin{array}{l}\text { Appointments } \\
\text { (per yr) }\end{array}$} & \multicolumn{2}{|c|}{ Cost (SGD per mth) } \\
\hline & & & Unsubsidised* & Subsidised $^{+}$ \\
\hline Referrals & & & 173.79 & 93.37 \\
\hline 1. Dietician referral (DM, L, HT) & Annually & 1 & & \\
\hline 2. Diabetic retinal photography (DM) & Annually & \multirow[t]{2}{*}{1} & & \\
\hline 3. Diabetic foot screening (DM) & Annually & & & \\
\hline 4. Podiatry (DM) & 2-weekly & 24 & & \\
\hline 5. Psychotherapy ${ }^{\ddagger}$ (DP) & 6-weekly & 8 & & \\
\hline 6. Physiotherapy (OA) & Monthly & 12 & & \\
\hline Laboratory tests & & & 14.49 & 10.04 \\
\hline 7. $\mathrm{HbA} 1 \mathrm{C}(\mathrm{DM})$ & 3-monthly & $\begin{array}{l}\text { At clinician } \\
\text { review }\end{array}$ & & \\
\hline 8. Electrocardiography ${ }^{\S}(\mathrm{DM}, \mathrm{L}, \mathrm{HT})$ & Annually & \multirow{7}{*}{$\begin{array}{l}1^{\S} \text { (for all annual } \\
\text { tests) }\end{array}$} & & \\
\hline 9. Fasting lipid profile $\left.{ }^{\S} \mathrm{L}\right)$ & Annually & & & \\
\hline 10. Fasting blood glucose ${ }^{\S}$ (DM) & Annually & & & \\
\hline 11. Urine albumin-to-creatinine ratio ${ }^{\S}(\mathrm{DM})$ & Annually & & & \\
\hline 12. Urea and electrolytes ${ }^{\S}(\mathrm{DM}, \mathrm{HT})$ & Annually & & & \\
\hline 13. Serum creatinine ${ }^{\S}(\mathrm{DM}, \mathrm{HT})$ & Annually & & & \\
\hline 14. Lung function test ${ }^{\S}(A)$ & Annually & & & \\
\hline \multicolumn{5}{|l|}{ Patient education } \\
\hline 15. Diabetic self-management education with care manager (DM) & Annually & 1 & 2.80 & 0.57 \\
\hline 16. Diabetic footcare and footwear (DM) & \multicolumn{4}{|c|}{ With podiatrist during diabetic foot screening } \\
\hline 17. Asthma education (A) & \multicolumn{4}{|c|}{ With care manager/pharmacist during medication collection } \\
\hline 18. Psychoeducation (DP) & \multicolumn{4}{|c|}{ With psychologist during psychotherapy } \\
\hline 19. Osteoarthritis education (OA) & \multicolumn{4}{|c|}{ With physiotherapist during physiotherapy } \\
\hline Others & & & 20.01 & 4.93 \\
\hline 20. Clinician review (A, DP, DM, L, HT, OA) & 3-monthly & 4 & & \\
\hline 21. Influenza vaccination (A) & Annually & 1 & & \\
\hline Total & & 53 & 211.09 & 108.91 \\
\hline
\end{tabular}

Clinical practice guidelines used for each recommendation are indicated in brackets. *Inclusive of GST. †After Ministry of Health subsidy, with GST absorbed. $¥$ Comprises cognitive-behavioural therapy and problem-solving therapy. §Typically performed 1 week before clinical review. A: asthma; DP: depression; DM: diabetes mellitus; GST: goods and services tax; HT: hypertension; L: dyslipidaemia; OA: osteoarthritis

\section{DISCUSSION}

Similar to Mdm Wong, about one in ten older adults in Singapore has six or more chronic conditions (unpublished data from NHGP). The cumulative treatment plan from six CPGs has created a treatment burden that is time-consuming, costly and disruptive to her daily living. The CPGs also inadequately address the issues of older adults with multimorbidity and patient-centred care. Our results highlight the various shortcomings of singledisease CPGs when managing patients with multimorbidity in Singapore, a finding that is consistent with previous studies from other countries. $^{(11,13,26)}$

Compared with a 2015 study in which patients with six conditions required up to 18 different medications, ${ }^{(12)} \mathrm{Mdm}$ Wong was prescribed 14 medications for her six conditions. This was due to differences in the selection of conditions and disease severity defined. ${ }^{(13)}$ In addition, the cumbersome pharmacological regimen involving a high pill burden and the complexity associated with preparing a large number of medications every day adds to the treatment burden. Therefore, polypharmacy is associated with increased medication errors, adverse drug events, drug interactions and hospital admissions. ${ }^{(27)}$ The 21 non-pharmacological recommendations for six conditions are comparable to those of previous studies, ${ }^{(11,13)}$ with differences due to the varying number of chronic conditions and the disease severity defined.

Russell et al and Yen et al have conducted studies to examine the time spent on HRAs in the American and Australian setting, respectively. ${ }^{(22,28)}$ In Singapore, ready-to-eat food and groceries are readily accessible close to residential areas, which may be different for patients residing in America and Australia. Therefore, in our study, Mdm Wong spends an average of 65 hours a month on HRAs, significantly lower than the 81 hours reported for six conditions by Buffel et al. ${ }^{(12)}$ Furthermore, for polyclinic appointments, the median time estimates for waiting time and time spent receiving healthcare are ten minutes and 15-25 minutes, respectively. These operational values obtained from the NHGP are conservative compared to the mean values of 47 minutes and 72 minutes, respectively, in the American Time Use Survey. ${ }^{(28)}$ Lastly, our patient had the option of bundled appointments. Compared to the average of seven appointments a 
Table II. Pharmacological recommendations from clinical practice guidelines for Mdm Wong.

\begin{tabular}{|c|c|c|c|c|}
\hline Drugs & Frequency & Pill burden (per day) & $\begin{array}{l}\text { Unsubsidised } \\
\text { cost* (per mth) }^{*} \text { (per }\end{array}$ & $\begin{array}{l}\text { Subsidised } \\
\text { cost }^{\dagger} \text { (per mth) }\end{array}$ \\
\hline \multicolumn{5}{|l|}{ Asthma } \\
\hline $\begin{array}{l}\text { Seretide Evohaler (fluticasone/ } \\
\text { salmeterol) 50/25 mg 2-puff BD }\end{array}$ & After breakfast, after dinner & 4 (puffs) & \multirow[t]{2}{*}{38.00} & \multirow[t]{2}{*}{8.30} \\
\hline $\begin{array}{l}\text { Ventolin Evohaler (salbutamol) } \\
100 \text { mg 2-puff PRN }^{\ddagger}\end{array}$ & After breakfast & 2 (puffs) & & \\
\hline \multicolumn{5}{|l|}{ Depression } \\
\hline Fluvoxamine $20 \mathrm{mg} \mathrm{OM}$ & After breakfast & 1 & 7.79 & 4.80 \\
\hline \multicolumn{5}{|l|}{ Diabetes mellitus } \\
\hline Metformin $850 \mathrm{mg}$ TDS & After breakfast, after lunch, after dinner & 3 & \multirow[t]{5}{*}{103.99} & \multirow[t]{5}{*}{33.56} \\
\hline Glipizide 10 mg BD & Before breakfast, before dinner & 4 & & \\
\hline Insulin glargine 24 units ON & After dinner & 1 (injection) & & \\
\hline Aspirin $100 \mathrm{mg}$ OM & After breakfast & 1 & & \\
\hline Omeprazole 20 mg BD & Before breakfast, before dinner & 2 & & \\
\hline \multicolumn{5}{|l|}{ Dyslipidaemia } \\
\hline Atorvastatin $40 \mathrm{mg}$ OD & After breakfast & 1 & 12.88 & 2.80 \\
\hline \multicolumn{5}{|l|}{ Hypertension } \\
\hline Telmisartan 80 mg OD & After breakfast & 1 & \multirow[t]{2}{*}{25.92} & \multirow[t]{2}{*}{16.48} \\
\hline Amlodipine $7.5 \mathrm{mg}$ OD & After breakfast & 1.5 & & \\
\hline \multicolumn{5}{|l|}{ Osteoarthritis } \\
\hline Glucosamine 500 mg TDS & After breakfast, after lunch, after dinner & 3 & \multirow[t]{3}{*}{48.06} & \multirow[t]{3}{*}{34.00} \\
\hline Paracetamol 1,000 mg TDS PRN & After breakfast, after lunch, after dinner & 6 & & \\
\hline Kefentech plasters 1 BD PRN & After breakfast, after dinner & 2 (plasters) & & \\
\hline Total & & $32.5^{\S}$ & 236.64 & 99.94 \\
\hline
\end{tabular}

*Inclusive of GST. †After Ministry of Health subsidy, with goods and services tax absorbed. ¥Assumes that Mdm Wong uses her Ventolin Evohaler daily before exercise. §Assumes that 1 injection/1 puff/1 plaster is equivalent to 1 pill. BD: twice daily; OD: once daily; OM: every morning; ON: every night; PRN: as needed; TDS: three times daily

Table III. Out-of-pocket treatment costs for Mdm Wong.

\begin{tabular}{|c|c|c|c|c|}
\hline \multirow[t]{2}{*}{ Component } & \multicolumn{2}{|c|}{ Unsubsidised cost* (SGD) } & \multicolumn{2}{|c|}{ Subsidised cost ${ }^{\dagger}$ (SGD) } \\
\hline & Per mth ${ }^{\neq}$ & Annual & Per $\mathbf{m t h}^{\ddagger}$ & Annual \\
\hline Pharmacological & 236.64 & $2,839.67$ & 99.94 & $1,199.24$ \\
\hline Non-pharmacological & 211.08 & $2,533.01$ & 108.91 & $1,306.90$ \\
\hline Total & 447.72 & $5,372.68$ & 208.85 & $2,506.14$ \\
\hline \multicolumn{5}{|l|}{ Out-of-pocket payment } \\
\hline After PGP§ & NA & NA & 104.42 & $1,253.07$ \\
\hline After CHAS" & NA & NA & NA & $713.07^{* *}$ \\
\hline
\end{tabular}

*Inclusive of GST. †After Ministry of Health subsidy, with GST absorbed. $¥$ Monthly costs were derived from annual costs divided across 12 months. §The PGP entitles patients to an additional 50\% off their bill for subsidised services. ๆCHAS for the Pioneer Generation enables patients to make claims of up to SGD 135/visit and a maximum of SGD 540/year from their Medisave account. **Value reflected is the annual out-of-pocket payment by Mdm Wong after subsidy of almost $90 \%$ for her healthcare bill. CHAS: Community Health Assist Scheme; GST: goods and services tax; NA: not applicable; PGP: Pioneer Generation Package

month from Buffel et al, ${ }^{(12)} \mathrm{Mdm}$ Wong only requires an average of four appointments per month. In Singapore, the polyclinics providing public primary healthcare make multiple healthcare services available at a single site, thereby allowing patients to make minimal trips and save time travelling to each appointment. Nevertheless, the allied health services that are available vary between polyclinics, and most polyclinics do not house all services on-site. Hence, while it is theoretically possible to attend multiple appointments in a single sitting (e.g. psychologist, physiotherapist and podiatrist on the same day), our study has not reflected that.
We estimated that the annual out-of-pocket payment by $\mathrm{Mdm}$ Wong would be SGD 713.07 despite the heavy subsidies of almost $90 \%$ of her healthcare bill. Without subsidies, Mdm Wong would have to spend almost $70 \%$ of her annuity each month and SGD 5,372.68 annually on healthcare alone, excluding travel expenses and other indirect costs. The annual economic burden borne by the healthcare system is estimated to be SGD 15,148 per patient with multimorbidity in Singapore, with healthcare costs and social care costs increasing by SGD 2,265 and SGD 3,177, respectively, with each additional chronic condition. ${ }^{(29)}$ Significant increases in healthcare utilisation and costs among patients with 


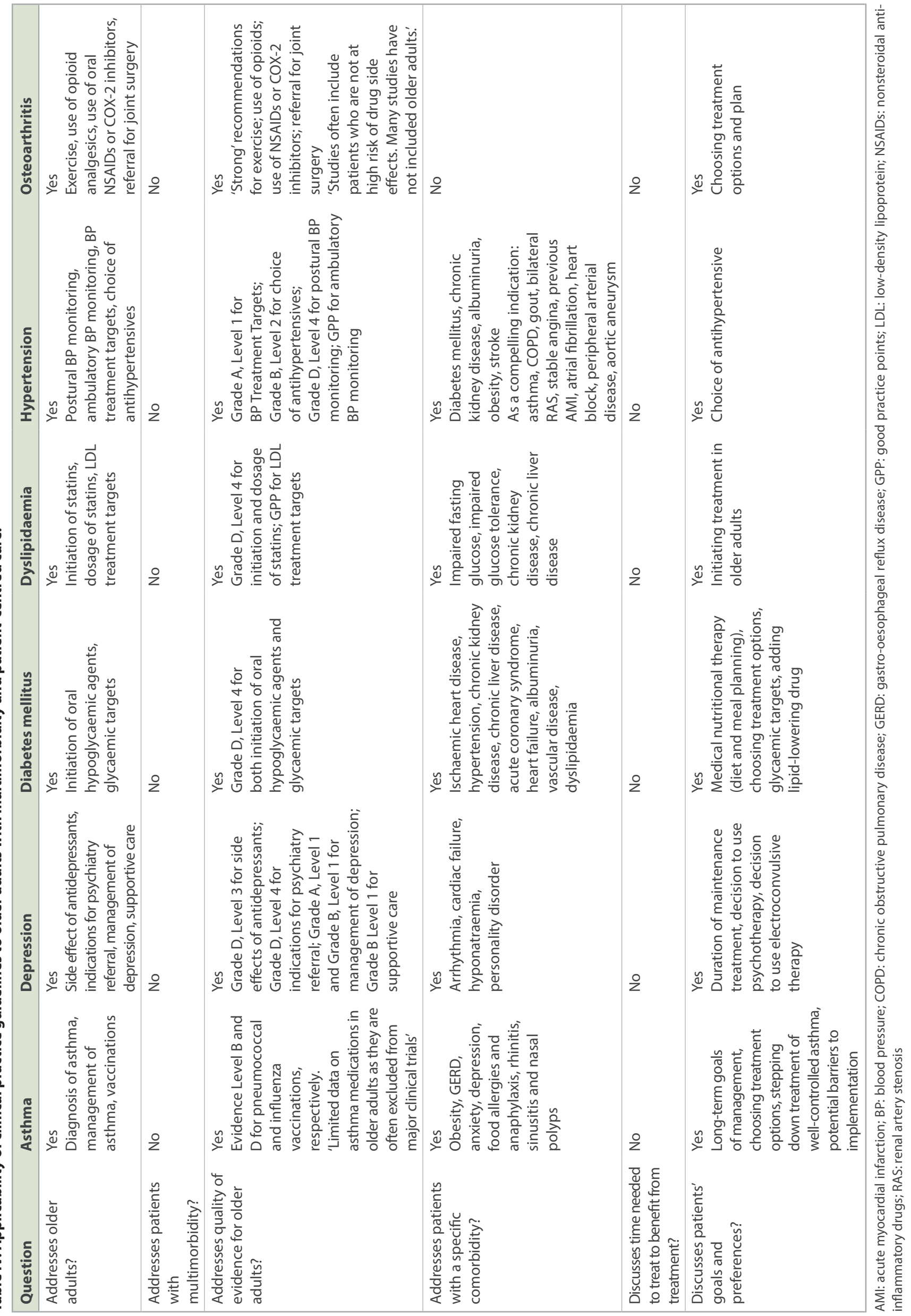


multimorbidity have been consistently demonstrated. According to a systematic review by Lehnert et al in 2011, total healthcare expenditures rose almost exponentially with the number of chronic conditions in several studies. ${ }^{(2)}$ Healthcare costs were up to 5.5 times higher in patients with multimorbidity compared to those with none or only one chronic condition, and each additional chronic condition was associated with increased costs of USD 2,382 per year. ${ }^{(1)}$

Chronic conditions represent a lifetime burden that impact not only health services, but also patients and their caregivers who work to incorporate the increasingly complex treatment regimens into their daily lives. ${ }^{(10)}$ Patients are significantly affected when they have to constantly juggle the demands of managing chronic conditions with other family, social and personal demands. ${ }^{(30)}$ The healthcare workload is balanced against the patient's capacity to manage their own health. ${ }^{(31)}$ When the healthcare workload exceeds the patient's capacity, they become overwhelmed by both the illness and treatment burden. Poor adherence, wasted resources and poor clinical outcomes ensue. ${ }^{(10)}$ A patient-centred approach focuses on achieving patients' targets for life and health while imposing the minimal potential treatment burden on their lives ${ }^{(32)}$ with an empathic and feasible treatment plan. ${ }^{(33)}$ Clinicians must continuously consider whether what is 'asked of' patients is achieving their goals or those of the health system. ${ }^{(34)}$

In our study, all six CPGs include patients' goals and preferences. While many have advocated for personalised care, there is limited evidence on the best practices to achieve this. ${ }^{(11)}$ One obvious barrier is the lack of information to aid clinical decisions, such as comparable information about the relative risks and benefits of different treatments. Future CPGs would need to incorporate the risks and benefits of prioritisation of care for each patient, while clinicians are trained to apply these principles. ${ }^{(35)}$ One approach to personalise recommendations is to report a 'payoff time', the time over which patients must comply with treatment to achieve the proposed benefit. ${ }^{(36)}$ For example, for a patient with diabetes mellitus and limited life expectancy who has difficulty achieving glycaemic targets on oral hypoglycaemic agents, the payoff time for preventing long-term complications using insulin should be balanced against the risk of hypoglycaemia and burden of regular blood glucose monitoring. ${ }^{(37)}$ This helps to identify patients who may not benefit from recommendations that have immediate risks and delayed benefits. ${ }^{(36)}$ If the payoff time is longer than the patient's life expectancy, a shared decision to remove a prescribed treatment can decrease treatment burden and improve patient-centred care. ${ }^{(37)}$

In our study, we found that there were a limited number of recommendations for older adults based on the highest level of evidence, and no recommendations for patients with multimorbidity. Currently, there is insufficient published evidence to guide clinicians in managing older adults with multimorbidity or supporting their preferences, as older adults are systematically excluded from clinical trials ${ }^{(38)}$ despite having the highest prevalence of multimorbidity. In future trials, older adults should be included and shared decision-making between patients and clinicians investigated in order to close this gap. ${ }^{(39)}$
We found that although most CPGs address the increased risk of drug interactions and adverse effects in older adults, none elaborated further on common or high-risk interactions. Furthermore, although the hypertension CPG has an extensive list of comorbidities, most are suggested as 'compelling indications' for specific medications, with no elaboration. While elaborating in CPGs to address all situations is unrealistic, their generalisability can be improved. CPGs should be cross-referenced explicitly to identify and demonstrate how to streamline synergistic recommendations and reconcile contradictory ones. ${ }^{(13)}$ Most importantly, future CPGs should move from a single-disease focus to a patient-centred approach. For example, the United Kingdom (UK) NICE guideline for multimorbidity explicitly recommends establishing the disease and treatment burden alongside patient preferences. ${ }^{(40)}$

Our study has several strengths. First, we identified local CPGs and used available time and cost data norms whenever possible to contextualise the treatment burden in a local setting. Secondly, we used median time norms to calculate time spent, which is more meaningful for data that is not normally distributed, compared to the use of mean values in previous studies. ${ }^{(12)}$

The present study also has some limitations. The full range of treatment burdens was not considered. Our hypothetical patient did not present with any disease exacerbations or acute intercurrent illnesses. Furthermore, we excluded recommendations that were not found in the six CPGs we adopted, such as age-appropriate cancer screening or vaccinations as well as the psychosocial aspects of her disease and treatment burden experienced. Therefore, the treatment burden we tabulated would not be realistic if Mdm Wong were to exist in real life.

In conclusion, current single-disease CPGs inadequately address the patient-centred care approach for older adults with multimorbidity. When applied cumulatively, they create an overwhelming treatment burden. Therefore, patients' goals and preferences must guide prioritisation of care such that treatment burden remains minimally disruptive to their lives. Developing future CPGs to deliver patient-centred rather than disease-focused care will be crucial to the management of multimorbidity.

\section{ACKNOWLEDGEMENTS}

This research was supported by the Singapore Ministry of Health's National Medical Research Council under the Centre Grant Programme (reference no. CGAug16C019).

\section{SUPLEMENTARY MATERIAL}

The appendices are available online at https://doi.org/10.11622/ smedj.2019109.

\section{REFERENCES}

1. Bähler C, Huber CA, Brüngger B, Reich O. Multimorbidity, health care utilization and costs in an elderly community-dwelling population: a claims data based observational study. BMC Health Serv Res 2015; 15:23.

2. Lehnert $\mathrm{T}$, Heider $\mathrm{D}$, Leicht $\mathrm{H}$, et al. Review: health care utilization and costs of elderly persons with multiple chronic conditions. Med Care Res Rev 2011; 68:387-420.

3. Salisbury C, Johnson L, Purdy S, Valderas JM, Montgomery AA. Epidemiology and impact of multimorbidity in primary care: a retrospective cohort study. $\mathrm{Br}$ J Gen Pract 2011; 61:e12-21.

4. Mercer SW, Salisbury C, Fortin M. ABC of Multimorbidity (ABC Series). 1st ed. 
K: John Wiley \& Sons Ltd, 2014

5. Guthrie B, Payne K, Alderson P, McMurdo ME, Mercer SW. Adapting clinical guidelines to take account of multimorbidity. BMJ 2012; 345:e6341.

6. Gallacher K, May CR, Montori VM, Mair FS. Understanding patients' experiences of treatment burden in chronic heart failure using normalization process theory. Ann Fam Med 2011; 9:235-43.

7. Gijsen R, Hoeymans N, Schellevis FG, et al. Causes and consequences of comorbidity: a review. J Clin Epidemiol 2001; 54:661-74.

8. Wolff JL, Starfield B, Anderson G. Prevalence, expenditures, and complications of multiple chronic conditions in the elderly. Arch Intern Med 2002; 162:2269-76.

9. Ministry of Health, Singapore. Ageing in Place in Singapore. Available at: http:// www.gs.org.sg/sg50conference/pdf/s4-1.pdf. Accessed August 26, 2019.

10. May C, Montori VM, Mair FS. We need minimally disruptive medicine. BM 2009; 339:b2803.

11. Boyd CM, Darer J, Boult C, et al. Clinical practice guidelines and quality of care for older patients with multiple comorbid diseases: implications for pay for performance. JAMA 2005; 294:716-24.

12. Buffel du Vaure C, Ravaud P, Baron G, et al. Potential workload in applying clinical practice guidelines for patients with chronic conditions and multimorbidity: a systematic analysis. BMJ Open 2016; 6:e010119.

13. Hughes LD, McMurdo ME, Guthrie B. Guidelines for people not for diseases: the challenges of applying UK clinical guidelines to people with multimorbidity. Age Ageing 2013; 42:62-9.

14. CPF Advisory Panel, Central Provident Fund, Singapore. Chapter 2: The Retirement Payouts and Sums. Available at: https://services.mom.gov.sg/ cpfpanel/media/recommendations/part1/Chapter\%202 The\%20Retirement $\% 20$ Payouts\%20and\%20Sums.pdf. Accessed August 25, 2018.

15. Ministry of Health, Singapore. Chronic Disease Management Programme. Handbook for Healthcare Professionals 2018. Available at: https://www. primarycarepages.sg/Documents/Practice\%20Management/CDMP\%20 Handbook\%20for\%20Healthcare\%20Professionals\%202018.pdf. Accessed August 25, 2018.

16. Ministry of Health, Singapore. MOH Clinical Practice Guidelines on Diabetes Mellitus. 2014. Available at: https://www.moh.gov.sg/hpp/doctors/guidelines/ GuidelineDetails/cpgmed_diabetes_mellitus. Accessed August 30, 2018.

17. Ministry of Health, Singapore. MOH Clinical Practice Guidelines on Lipids. 2016 Available at: https://www.moh.gov.sg/hpp/doctors/guidelines/GuidelineDetails/ cpgmed_lipids. Accessed August 30, 2018.

18. Ministry of Health, Singapore. $\mathrm{MOH}$ Clinical Practice Guidelines on Hypertension. 2017. Available at: https://www.moh.gov.sg/hpp/doctors/ guidelines/GuidelineDetails/cpgmed_hypertension. Accessed August 30, 2018

19. 2018 GINA Report, Global Strategy for Asthma Management and Prevention. In: Global Initiative for Asthma [online]. Available at: https://ginasthma.org/ gina-reports/. Accessed August 30, 2018.

20. Ministry of Health, Singapore. MOH Clinical Practice Guidelines on Depression. 2012. Available at: https://www.moh.gov.sg/docs/librariesprovider4/guidelines/ depression-cpg_r14_final.pdf. Accessed August 30, 2018.

21. National Clinical Guideline Centre (UK). Osteoarthritis: Care and Management in Adults. London: National Institute for Health and Care Excellence (UK); 2014.

22. Yen LE, McRae IS, Jowsey T, Bagheri N. Time spent on health related activity by older Australians with diabetes. J Diabetes Metab Disord 2013; 12:33.

23. Safford MM, Russell L, Suh DC, Roman S, Pogach L. How much time do patients with diabetes spend on self-care? J Am Board Fam Pract 2005; 18:262-70.

24. Ministry of Finance, Singapore. Overview: Pioneer Generation Package. Available at: https://www.pioneers.sg/en-sg/Pages/Overview.aspx. Accessed September 15, 2018.

25. Community Health Assist Scheme, Singapore. CHAS Subsidies. Available at: https://www.chas.sg/content.aspx?id=636. Accessed September 15, 2018

26. Mutasingwa DR, Ge H, Upshur RE. How applicable are clinical practice guidelines to elderly patients with comorbidities? Can Fam Physician 2011; 57:e253-62.

27. Maher RL, Hanlon J, Hajjar ER. Clinical consequences of polypharmacy in elderly. Expert Opin Drug Saf 2014; 13:57-65

28. Russell LB, Ibuka Y, Carr D. How much time do patients spend on outpatient visits?: the American time use survey. Patient 2008; 1:211-22.

29. Picco L, Achilla E, Abdin E, et al. Economic burden of multimorbidity among older adults: impact on healthcare and societal costs. BMC Health Serv Res 2016; 16:173.

30. Jeon $\mathrm{YH}$, Jowsey $\mathrm{T}$, Yen $\mathrm{L}$, et al. Achieving a balanced life in the face of chronic illness. Aust J Prim Health 2010; 16:66-74.

31. Shippee ND, Shah ND, May CR, Mair FS, Montori VM. Cumulative complexity: a functional, patient-centered model of patient complexity can improve research and practice. J Clin Epidemiol 2012; 65:1041-51.

32. Leppin AL, Montori VM, Gionfriddo MR. Minimally disruptive medicine: a pragmatically comprehensive model for delivering care to patients with multiple chronic conditions. Healthcare (Basel) 2015; 3:50-63.

33. Boehmer KR, Gionfriddo MR, Rodriguez-Gutierrez R, et al. Patient capacity and constraints in the experience of chronic disease: a qualitative systematic review and thematic synthesis. BMC Fam Pract 2016; 17:127.

34. Trevena L. Minimally disruptive medicine for patients with complex multimorbidity. Aust J Gen Pract 2018; 47:175-9.

35. Garber AM. Evidence-based guidelines as a foundation for performance incentives. Health Aff (Millwood) 2005; 24:174-9.

36. Braithwaite RS, Fiellin D, Justice AC. The payoff time: a flexible framework to help clinicians decide when patients with comorbid disease are not likely to benefit from practice guidelines. Med Care 2009; 47:610-7.

37. Wyatt KD, Stuart LM, Brito JP, et al. Out of context: clinical practice guidelines and patients with multiple chronic conditions: a systematic review. Med Care 2014; 52 Suppl 3:S92-S100.

38. McMurdo ME, Witham MD, Gillespie ND. Including older people in clinical research. BMJ 2005; 331:1036-7.

39. Elwyn G, Edwards A, Britten N. What information do patients need about medicines? "Doing prescribing": how doctors can be more effective. BMJ 2003; 327:864-7.

40. The National Institute for Health and Care Excellence. Multimorbidity: clinical assessment and management. NICE guideline [NG56]. 2016. Available at: https://www.nice.org.uk/guidance/ng56. Accessed September 5, 2018. 


\section{APPENDIX 1}

Clinical practice guideline recommendations for 72-year-old hypothetical patient.

\begin{tabular}{|c|c|}
\hline Disease (Publisher, Yr) & Recommendation \\
\hline \multirow[t]{4}{*}{$\begin{array}{l}\text { Asthma (Global Initiative for } \\
\text { Asthma [GINA], 2018) }\end{array}$} & $\begin{array}{l}\text { Non-pharmacological } \\
\text { - Patient education } \\
\text { 1. Asthma information } \\
\text { 2. Inhaler technique/skills } \\
\text { 3. Adherence } \\
\text { - Asthma self-management } \\
\text { 1. Written asthma action plan } \\
\text { 2. Self-monitoring of symptoms and/or lung infection } \\
\text { 3. Regular medical review } \\
\text { - Diet (high in fruits and vegetables) } \\
\text { - Smoking cessation/avoidance of exposure to tobacco smoke } \\
\text { - } \quad \text { Wxercise (with advice on management of exercise-induced bronchoconstriction) } \\
\text { Weight loss if obese } \\
\text { 1. Weight reduction programme plus twice-weekly aerobic and strength } \\
\text { 2. Quercises } \\
\text { Avoidance of exacerbating factors } \\
\text { 1. Avoid occupational sensitisers for occupational asthma } \\
\text { 2. Avoid medications that may make asthma worse } \\
\text { 3. Avoid indoor air pollution } \\
\text { 4. Avoid outdoor allergens } \\
\text { - Annual influenza vaccination (but not pneumococcal vaccination) } \\
\text { Breathing exercises as an adjunct }\end{array}$ \\
\hline & $\begin{array}{l}\text { Pharmacological } \\
\text { - } \quad \text { See GINA's stepwise approach for pharmacological therapy of asthma } \\
\text { - } \quad \text { Allergen immunotherapy for adult patients with allergic rhinitis and sensitised to } \\
\text { house dust mites }\end{array}$ \\
\hline & $\begin{array}{l}\text { Monitoring } \\
\text { - } \quad \text { Self-monitoring of symptoms and/or peak expiratory flow } \\
\text { - } \quad \text { A written asthma action plan } \\
\text { - } \quad \text { Regular medical review }\end{array}$ \\
\hline & 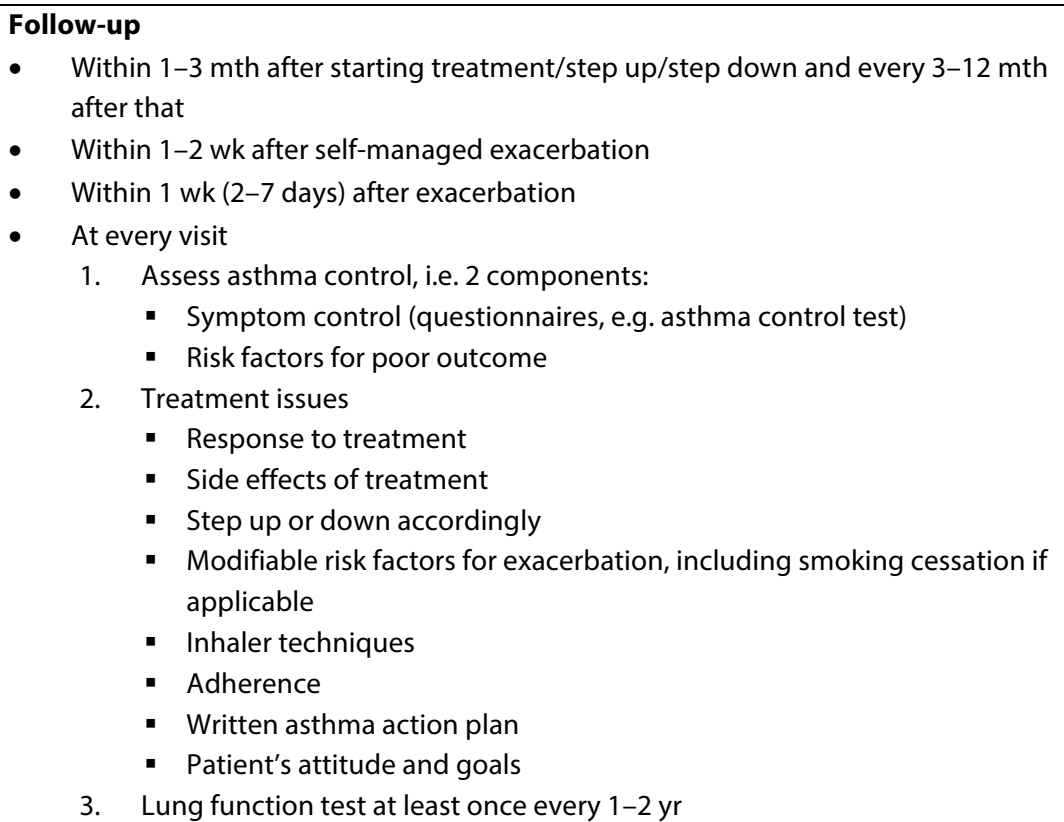 \\
\hline $\begin{array}{l}\text { Depression (Ministry of Health } \\
\text { Singapore, 2012) }\end{array}$ & $\begin{array}{l}\text { Non-pharmacological } \\
\text { - Psychoeducation }\end{array}$ \\
\hline
\end{tabular}




\begin{tabular}{|c|c|}
\hline Disease (Publisher, Yr) & Recommendation \\
\hline & $\begin{array}{l}\text { 1. Patient education about disease ('depression should be explained as a } \\
\text { medical illness that is associated with changes in neurochemicals and brain } \\
\text { functioning') } \\
\text { 2. Lifestyle changes such as exercise and stress reduction } \\
\text { Psychotherapy } \\
\text { 1. Cognitive behavourial therapy for distorted negative thoughts } \\
\text { 2. Interpersonal therapy for interpersonal difficulties } \\
\text { 3. Psychodynamic-interpersonal therapy for interpersonal difficulties } \\
\text { 4. Problem-solving therapy for primary care patients with mild depression } \\
\text { - Family intervention } \\
\text { 1. Family involvement where indicated and with patient's agreement } \\
\text { 2. Marital or couple therapy for significant marital distress } \\
\text { Supportive care for older adults and their caregivers }\end{array}$ \\
\hline & $\begin{array}{l}\text { Pharmacological } \\
\text { - Antidepressants } \\
\text { 1. SSRIs (1st line) } \\
\text { 2. Serotonin-noradrenaline reuptake inhibitors } \\
\text { 3. Tricyclic antidepressants } \\
\text { 4. Noradrenergic and specific serotonergic antidepressants } \\
\text { 5. Noradrenaline-dopamine reuptake inhibitor } \\
\text { Depression in older adults } \\
\text { 1. Mild/moderate: SSRI or psychotherapy } \\
\text { 2. Severe: SSRI and psychotherapy } \\
\text { Adjuncts } \\
\text { - Lithium augmentation } \\
\text { - Thyroid hormone augmentation (levothyroxine or triiodothyronine) }\end{array}$ \\
\hline & $\begin{array}{l}\text { Monitoring } \\
\text { NA }\end{array}$ \\
\hline & $\begin{array}{l}\text { Follow-up } \\
\text { Frequency of visits not specified and depends on the severity of the depression, suicide } \\
\text { risk, the patient's cooperation and the availability of social support }\end{array}$ \\
\hline $\begin{array}{l}\text { Diabetes mellitus (Ministry of } \\
\text { Health Singapore, 2014) }\end{array}$ & $\begin{array}{l}\text { Non-pharmacological } \\
\text { - Diet (medical nutritional therapy in consultation with dietician) } \\
\text { 1. Balanced diet ( } 50 \%-60 \% \text { carbohydrate, } 15 \%-20 \% \text { protein, }<30 \% \text { fat) } \\
\text { 2. Trans fat }<1 \% \text {, cholesterol }<200 \mathrm{mg} / \text { day (same as general population) } \\
\text { 3. Dietary fibre } 20-35 \mathrm{~g} / \text { day } \\
\text { 4. Consistently distributed carbohydrate intake through the day } \\
\text { 5. Low protein if CKD present (reduce to } 0.8-1.0 \mathrm{~g} / \mathrm{kg} / \text { day) } \\
\text { 6. Salt }<2 \mathrm{~g} / \text { day if hypertension } \\
\text { - Gradual weight loss of } 5 \%-10 \% \text { body weight if overweight/obese }(0.25-1.0 \mathrm{~kg} / \mathrm{wk} \text { ) } \\
\text { - Smoking cessation } \\
\text { - Alcohol abstinence of no more than } 3 \text { drinks/day (male) or } 2 \text { drinks/day (female) } \\
\text { - Exercise } \\
\text { 1. At least } 150 \text { min/wk } \\
\text { 2. Moderate-to-vigorous aerobic exercise } \\
\text { 3. Over } \geq 3 \text { days of the week } \\
\text { 4. No more than } 2 \text { consecutive days } \\
\text { Foot care } \\
\text { 1. Foot care education and footwear advice } \\
\text { 2. Use of appropriate footwear } \\
\text { 3. Daily foot checks } \\
\text { Diabetes mellitus self-management education } \\
\text { Assessment of psychological and social well-being }\end{array}$ \\
\hline & $\begin{array}{l}\text { Pharmacological } \\
\text { - Oral hypoglycaemia agents } \\
\text { 1. Metformin as 1st line }\end{array}$ \\
\hline
\end{tabular}




\begin{tabular}{|c|c|}
\hline Disease (Publisher, Yr) & Recommendation \\
\hline & $\begin{array}{l}\text { 2. Sulfonylurea/dipeptidyl peptidase-4 inhibitor/alpha-galactosidase inhibitor } \\
\text { are acceptable alternatives as } 1 \text { st line } \\
\text { - } \quad \text { Insulin as appropriate } \\
\text { - } \quad \text { Lipids: statins if appropriate } \\
\text { - BP: ACE-I or ARB if appropriate } \\
\text { - Low-dose aspirin for primary prevention if appropriate }\end{array}$ \\
\hline & $\begin{array}{l}\text { Monitoring } \\
\text { Self-monitoring of blood glucose (frequency unspecified) }\end{array}$ \\
\hline & $\begin{array}{l}\text { Follow-up } \\
\text { - } \quad \text { At every visit, measure } \mathrm{HbA1c,BP} \text { and BMI and evaluate self-monitoring of blood } \\
\text { glucose } \\
\text { - } \quad \text { Measure HbA1c ever } 3-6 \mathrm{mth} \\
\text { - } \quad \text { Measure fasting lipids and serum creatinine at least annually } \\
\text { - } \quad \text { Urine albumin excretion, diabetic retinal photography/ophthalmology referral and } \\
\quad \text { foot examination (distal pulses) done annually }\end{array}$ \\
\hline \multirow[t]{4}{*}{$\begin{array}{l}\text { Dyslipidaemia (Ministry of } \\
\text { Health Singapore, 2016) }\end{array}$} & $\begin{array}{l}\text { Non-pharmacological } \\
\text { Diet } \\
\text { 1. Rich in wholegrain foods, vegetables, fruits, legumes, nuts, fish, unsaturated } \\
\text { oils } \\
\text { 2. Low in trans fat, saturated fat, cholesterol, refined grains } \\
\text { 3. Total fat intake } 25 \%-34 \% \text {, saturated fat }<7 \% \text {, polyunsaturated fat } \sim 10 \% \\
\text { 4. Trans fat }<1 \% \text { or }<2 \mathrm{~g} / \text { day, cholesterol }<300 \mathrm{mg} / \text { day } \\
\text { 5. Simple sugars (monosaccharides and disaccharides) }<10 \% \text { if high } \\
\text { 6. } 25-30 \mathrm{~g} / \text { day dietary fibre (increasing whole grains, fruits and vegetables, and } \\
\text { - } \text { - Weducing processed grains and sugar) } \\
\text { - Saturated fat should be replaced with mono- and polysaturated fat } \\
\text { - Alcohol abstinence of no more than } 3 \text { drinks/day (male) or } 2 \text { drinks/day (female) } \\
\text { - Exercise } \\
\text { 1. } 30-60 \text { min/day ( } 150-300 \text { min/wk) } \\
\text { 2. Moderate-intensity aerobic exercise } \\
\text { 3. 5-7 days a week }\end{array}$ \\
\hline & $\begin{array}{l}\text { Pharmacological } \\
\text { - Lipid-lowering agents } \\
\text { 1. Statins } \\
\text { 2. Ezetimibe } \\
\text { 3. Resins (bile acid sequestrants) } \\
\text { 4. Fibrates } \\
\text { 5. Niacin } \\
\text { 6. Omega-3 fish oil } \\
\text { Choice of lipid-lowering agent based on which lipid profile is deranged }\end{array}$ \\
\hline & $\begin{array}{l}\text { Monitoring } \\
\text { NA }\end{array}$ \\
\hline & $\begin{array}{l}\text { Follow-up } \\
\text { Aspartate transaminase, alanine transaminase and creatine kinase measured at baseline } \\
\text { and repeated only if symptomatic }\end{array}$ \\
\hline $\begin{array}{l}\text { Hypertension (Ministry of Health } \\
\text { Singapore, 2017) }\end{array}$ & $\begin{array}{l}\text { Non-pharmacological } \\
\text { - Diet } \\
\text { 1. Increase vegetables, fruits and low-fat dairy products } \\
\text { 2. Decrease saturated and total fats } \\
\text { 3. Low salts }(5-6 \mathrm{~g} / \mathrm{day}) \\
\text { - Weight loss to } \mathrm{BMI}<23 \mathrm{~kg} / \mathrm{m}^{2} \text { and waist circumference }<90 \mathrm{~cm} \text { (male) } \text { or }<80 \mathrm{~cm} \\
\text { (female) } \\
\text { - Smoking cessation } \\
\text { - Alcohol abstinence of no more than } 2 \text { drinks/day (male) or } 1 \text { drink/day (female) }\end{array}$ \\
\hline
\end{tabular}




\begin{tabular}{|c|c|}
\hline Disease (Publisher, Yr) & Recommendation \\
\hline & $\begin{array}{l}\text { - } \text { Exercise } \\
\text { 1. At least } 30 \mathrm{~min} / \text { day }(150 \mathrm{~min} / \mathrm{wk}) \\
\text { 2. Moderate-intensity dynamic exercise } \\
\text { 3. } 5-7 \text { days a week } \\
\text { - Patient education } \\
\text { 1. Lifestyle modification } \\
\text { 2. Medication adherence }\end{array}$ \\
\hline & $\begin{array}{l}\text { Pharmacological } \\
\text { - Antihypertensive agents } \\
\text { - ACE-I } \\
\text { - Diuretics (loop, thiazide, thiazide-like) } \\
\text { - Calcium-channel blocker } \\
\text { - Beta blockers } \\
\text { Consider compelling indications }\end{array}$ \\
\hline & $\begin{array}{l}\text { Monitoring } \\
\text { Home BP monitoring not mentioned except for white-coat hypertension }\end{array}$ \\
\hline & $\begin{array}{l}\text { Follow-up } \\
\text { - } \quad \text { At every visit, check patient education on lifestyle modification and medication } \\
\text { adherence } \\
\text { - } \quad \text { BP monitoring every } 3-12 \mathrm{mth} \\
\text { - } \quad \text { BMl, fasting glucose, fasting lipid profile, urea and electrolytes, creatinine, and urine } \\
\text { albumin excretion measured at least annually, or more frequently as per individual } \\
\text { risk profile } \\
\text { - } \quad \text { ECG as per individual risk and cardiac profile }\end{array}$ \\
\hline \multirow[t]{4}{*}{$\begin{array}{l}\text { Osteoarthritis (National Institute } \\
\text { for Health and Care Excellence, } \\
\text { 2014) }\end{array}$} & $\begin{array}{l}\text { Non-pharmacological } \\
\text { - } \quad \text { Patient education } \\
\text { - } \quad \text { Exercise } \\
\text { 1. Local muscle strengthening } \\
\text { 2. General aerobic fitness } \\
\text { 3. Manipulation and stretching as adjunct } \\
\text { - Weight loss if overweight or obese } \\
\text { - } \quad \text { Appropriate footwear (with shock-absorbing properties_ } \\
\text { - Activity pacing } \\
\text { Adjuncts } \\
\text { - Thermotherapy } \\
\text { - Transcutaneous electrical nerve stimulation for pain relief } \\
\text { - } \quad \text { Bracing, joint supports or insoles for pain/instability } \\
\text { - } \quad \text { Assistive devices (walking sticks, tap turners) if there are problems with activities of } \\
\text { daily living }\end{array}$ \\
\hline & $\begin{array}{l}\text { Pharmacological } \\
\text { - Topical analgesia } \\
\text { 1. Topical NSAIDs } \\
\text { - Oral analgesia } \\
\text { 1. Paracetamol } \\
\text { 2. Oral NSAIDs } \\
\text { 3. COX-2 inhibitors } \\
\text { 4. Opioids } \\
\text { - Proton pump inhibitor co-prescribed with oral NSAIDs/COX-2 inhibitors } \\
\text { Adjuncts } \\
\text { - Topical capsaicin } \\
\text { - Intra-articular corticosteroid injections }\end{array}$ \\
\hline & $\begin{array}{l}\text { Monitoring } \\
\text { NA }\end{array}$ \\
\hline & $\begin{array}{l}\text { Follow-up } \\
\text { - Annual follow-up if troublesome joint pain, more than } 1 \text { joint with symptoms, more } \\
\text { than } 1 \text { comorbidity or taking regular medications for } O A\end{array}$ \\
\hline
\end{tabular}




\begin{tabular}{|c|c|}
\hline Disease (Publisher, Yr) & Recommendation \\
\hline & $\begin{array}{l}\text { - At every visit: } \\
\text { 1. Monitor symptoms and ongoing impact on activities of daily living and } \\
\text { 2. Muality of life } \\
\text { 3. Discuss patient's knowledge of the condition, ideas, concerns, expectations, } \\
\text { preferences and access to healthcare } \\
\text { 4. Effectiveness and tolerability of treatment } \\
\text { 5. Support self-management }\end{array}$ \\
\hline
\end{tabular}

ACE-l: angiotensin-converting enzyme inhibitor; ARB: angiotensin II receptor blocker; BMl: body mass index; BP: blood pressure; CKD: chronic kidney disease; ECG: electrocardiography; HbA1c: glycated haemoglobin; NSAID: nonsteroidal anti-inflammatory drug; SSRI: serotonin-specific reuptake inhibitors 


\section{APPENDIX 2}

\section{Chronic conditions selected from the Chronic Disease Management Programme: ${ }^{(15)}$}

Conditions with established disease management programmes (requiring reporting of clinical indicators):

1. Diabetes mellitus and pre-diabetes mellitus*

2. Hypertension*

3. Lipid disorders*

4. Asthma*

5. Chronic obstructive pulmonary disease

6. Chronic kidney disease (nephritis/nephrosis)

Mental illnesses (requiring participation of clinic/doctor in a shared care programme):

7. Schizophrenia

8. Major depression*

9. Bipolar disorder

10. Anxiety

Other chronic conditions:

11. Stroke

12. Dementia

13. Osteoarthritis*

14. Parkinson's disease

15. Benign prostatic hyperplasia

16. Epilepsy

17. Osteoporosis

18. Psoriasis

19. Rheumatoid arthritis

20. Ischaemic heart disease

${ }^{*}$ Chronic conditions selected.

Selected chronic conditions and CPGs

\begin{tabular}{|l|l|l|l|}
\hline Guideline focus & Title & Organisation & Yr \\
\hline Asthma & $\begin{array}{l}\text { Global Strategy for Asthma } \\
\text { Management and Prevention }\end{array}$ & Global Initiative for Asthma & 2018 \\
\hline Depression & Depression & Ministry of Health Singapore & 2012 \\
\hline Diabetes mellitus & Diabetes mellitus & Ministry of Health Singapore & 2014 \\
\hline Dyslipidaemia & Lipids & Ministry of Health Singapore & 2016 \\
\hline Hypertension & Hypertension & Ministry of Health Singapore & 2017 \\
\hline Osteoarthritis & $\begin{array}{l}\text { Osteoarthritis: Care and } \\
\text { Management in Adults }\end{array}$ & National Institute for Health and Care Excellence & 2014 \\
\hline
\end{tabular}


APPENDIX 3

Overall time spent on health-related activities.

\begin{tabular}{|l|l|l|l|}
\hline Time spent on activity & Median time (min/day) & Time spent (hr/mth) & Time spent (hr/day) \\
\hline Taking medications* & 24.0 & 12.00 & 0.40 \\
\hline Following diet† & 32.0 & 16.00 & 0.53 \\
\hline Home monitoring & 17.3 & 8.67 & 0.29 \\
\hline Exerciseł & 60.0 & 20.00 & 0.67 \\
\hline $\begin{array}{l}\text { Attending appointments } \\
\text { (without buffer)§ }\end{array}$ & - & 5.62 & 0.19 \\
\hline $\begin{array}{l}\text { Attending appointments } \\
\text { (with buffer)§ }\end{array}$ & - & 7.87 & 0.26 \\
\hline Total without buffer time & - & 62.28 & 2.08 \\
\hline Total with buffer time & - & 64.53 & 2.15 \\
\hline
\end{tabular}

*Composite of three components: time to sort medications, prepare medications and take medications. Median time was derived from 20 $\mathrm{min} /$ day spent by patients with $>10$ medications(22) and 4 min/episode of insulin administration.(23) †Composite of two components: time to prepare food and shopping for food. Median time was derived from $30 \mathrm{~min} /$ day for preparing food and $1 \mathrm{hr} / \mathrm{mth}$ ( $2 \mathrm{~min} /$ day) for shopping for food.(22) ₹Composite of two components: time spent engaging in exercise itself and time spent on preparation and wash-up. We assume that our hypothetical patient spends $30 \mathrm{~min}$ a day engaging in exercise for 5 days/wk ( 20 days/mth) as per CPG recommendations. We arbitrarily decided that time spent on preparation and wash-up amounts to $30 \mathrm{~min} / \mathrm{session}$. This is because clinicians will likely recommend water-based physical activities instead of land-based activities given our patient's bilateral osteoarthritis of the knees. §Composite of three components: travelling time, waiting time and time for the appointment itself. Values were derived from our calculations using operational time norms from National Healthcare Group Polyclinic 
APPENDIX 4

Time spent attending appointments

\begin{tabular}{|c|c|c|c|c|c|}
\hline \multirow[t]{2}{*}{ Activity/care } & \multicolumn{2}{|c|}{ Time (min/unit activity) } & \multirow{2}{*}{$\begin{array}{l}\text { Frequency of } \\
\text { activity } \\
\text { (times/yr) }\end{array}$} & \multicolumn{2}{|c|}{ Time (hr/mth) } \\
\hline & $\begin{array}{l}\text { Without } \\
\text { buffer }\end{array}$ & With buffer* & & $\begin{array}{l}\text { Without } \\
\text { buffer }\end{array}$ & $\begin{array}{l}\text { With } \\
\text { buffer* }\end{array}$ \\
\hline Clinician review + HbA1c & 95 & \multirow[t]{6}{*}{125} & \multirow[t]{6}{*}{4} & \multirow[t]{6}{*}{0.53} & \multirow[t]{6}{*}{0.69} \\
\hline Travel $^{\dagger}$ & 30 & & & & \\
\hline Clinical review & 25 & & & & \\
\hline $\mathrm{HbA} 1 \mathrm{c}^{\ddagger}$ & 15 & & & & \\
\hline Collect medications (pharmacy) & 15 & & & & \\
\hline Check out & 10 & & & & \\
\hline Influenza vaccination & 55 & \multirow[t]{4}{*}{85} & \multirow[t]{4}{*}{1} & \multirow[t]{4}{*}{0.08} & \multirow[t]{4}{*}{0.12} \\
\hline Travel $^{\dagger}$ & 30 & & & & \\
\hline Administer influenza vaccine ${ }^{\ddagger}$ & 15 & & & & \\
\hline Check out & 10 & & & & \\
\hline Dietician referral & 65 & \multirow[t]{4}{*}{95} & \multirow[t]{4}{*}{1} & \multirow[t]{4}{*}{0.09} & \multirow[t]{4}{*}{0.13} \\
\hline Travel $^{\dagger}$ & 30 & & & & \\
\hline Dietician review $^{\ddagger}$ & 25 & & & & \\
\hline Check out & 10 & & & & \\
\hline $\begin{array}{l}\text { Diabetic foot screening + diabetic } \\
\text { retinal photography }\end{array}$ & 90 & \multirow[t]{5}{*}{120} & \multirow[t]{5}{*}{1} & \multirow[t]{5}{*}{0.13} & \multirow[t]{5}{*}{0.17} \\
\hline Travel $^{\dagger}$ & 30 & & & & \\
\hline Diabetic foot screening $^{\ddagger}$ & 25 & & & & \\
\hline Diabetic retinal photography ${ }^{\ddagger}$ & 25 & & & & \\
\hline Check out & 10 & & & & \\
\hline Podiatry session & 65 & 95 & 24 & 2.17 & 3.17 \\
\hline Travel $^{\dagger}$ & 30 & & & & \\
\hline Podiatrist review ${ }^{\ddagger}$ & 25 & & & & \\
\hline Diabetic foot education & 25 & & & & \\
\hline Check out & 10 & & & & \\
\hline Psychology session & 95 & 125 & 8 & 1.06 & 1.39 \\
\hline Travel $^{\dagger}$ & 30 & & & & \\
\hline Psychotherapy & 55 & & & & \\
\hline Psychoeducation & 55 & & & & \\
\hline Check out & 10 & & & & \\
\hline Physiotherapy session & 80 & 110 & 12 & 1.33 & 1.83 \\
\hline Travel $^{\dagger}$ & 30 & & & & \\
\hline Physiotherapy $^{\ddagger}$ & 40 & & & & \\
\hline Osteoarthritis education & & & & & \\
\hline Check out & 10 & & & & \\
\hline DM self-education management & 65 & 95 & 1 & 0.09 & 0.13 \\
\hline Travel $^{\dagger}$ & 30 & & & & \\
\hline DSME itself $^{\ddagger}$ & 25 & & & & \\
\hline Check out & 10 & & & & \\
\hline Asthma education $^{\S}$ & 15 & 45 & 1 & 0.02 & 0.06 \\
\hline Investigations/laboratory tests & 95 & 125 & 1 & 0.13 & 0.17 \\
\hline Travel $^{\dagger}$ & 30 & & & & \\
\hline Electrocardiography & 15 & & & & \\
\hline Fasting lipid profile & $15^{\S}$ & & & & \\
\hline Fasting blood glucose & & & & & \\
\hline Urine albumin-creatinine ratio & & & & & \\
\hline Urea and electrolytes & & & & & \\
\hline Serum creatinine & & & & & \\
\hline Lung function test & 25 & & & & \\
\hline Check out & 10 & & & & \\
\hline Total time spent & & & & 5.62 & 7.87 \\
\hline
\end{tabular}


*For each appointment, we calculated time spent as if more time was required due to unforeseen circumstances, such as missing the bus or exceptionally high patient volume in the polyclinics. This 'buffer time' was arbitrarily decided to be 30 min. †We arbitrarily decided that our hypothetical patient lives $15 \mathrm{~min}$ away from the neighbourhood polyclinic. Travelling time of 30 min indicated is for two-way travel from home to polyclinic and back. ¥Time indicated is inclusive of waiting time of $10 \mathrm{~min}$, an approximation of median waiting time data obtained from operational data from NHGP. §Specific activities: (a) time spent on clinical review with the clinician was taken to be 15 min excluding waiting time, an approximation of median consultation time obtained from operational data from NHGP; (b) time spent on performing all haematological investigations was taken to be $5 \mathrm{~min}$, excluding waiting time, as they would be done in the same sitting; and (c) for asthma education, time spent excludes travelling time, as the patient travels to the care manager during diabetic self-management education or the pharmacist during medication collection and it is not considered a separate appointment. DM: diabetes mellitus; DSME: diabetes self-management education; NHGP: National Healthcare Group Polyclinics

Time spent on home monitoring.

\begin{tabular}{|c|c|c|c|c|}
\hline $\begin{array}{l}\text { Home monitoring } \\
\text { activity }\end{array}$ & $\begin{array}{l}\text { Median time } \\
\text { (min/unit activity) }\end{array}$ & $\begin{array}{l}\text { Frequency } \\
\text { (times/wk) }\end{array}$ & Time (min/mth) & Time (hr/mth) \\
\hline Capillary blood glucose* & 5 & 3 & 60 & 1.00 \\
\hline Foot check ${ }^{\dagger}$ & 10 & 7 & 280 & 4.67 \\
\hline BP monitoring $^{\ddagger}$ & 10 & 1 & 40 & 0.67 \\
\hline Asthma symptoms/PEF & 5 & 7 & 140 & 2.33 \\
\hline Total time spent & & & 520 & 8.67 \\
\hline
\end{tabular}

*Time taken for capillary blood glucose monitoring was obtained from the literature.(22) +Time taken for foot care was obtained from the literature.(23) $¥$ We assumed that the time taken for BP monitoring is $10 \mathrm{~min}$ each, as most protocols recommend 5 min of rest before measurement and taking $\geq 2$ readings with a full minute in between. §To our knowledge, there are no studies on time taken for asthma selfmonitoring. We assumed that the time taken for disease monitoring of a single chronic condition is approximately $5 \mathrm{~min} /$ day, similar to capillary blood glucose monitoring. BP: blood pressure; PEF: peak expiratory flow 